\title{
Association between Obesity and Blood pressure incidence among Minia University Students, Upper Egypt
}

\author{
Medhat A. Salah and Abdelhamid S. Abobaker \\ Department of anatomy, faculty of medicine, Minia University, Egypt \\ Correspondence Author: Medhat A. Salah, Department of anatomy, faculty of medicine, Minia University, Egypt
}

Received date: 15 August 2019, Accepted date: 30 September 2019, Online date: 28 October 2019

Copyright: () 2019 Medhat A. Salah and Abdelhamid S. Abobaker, This is an open-access article distributed under the terms of the Creative Commons Attribution License, which permits unrestricted use, distribution, and reproduction in any medium, provided the original author and source are credited.

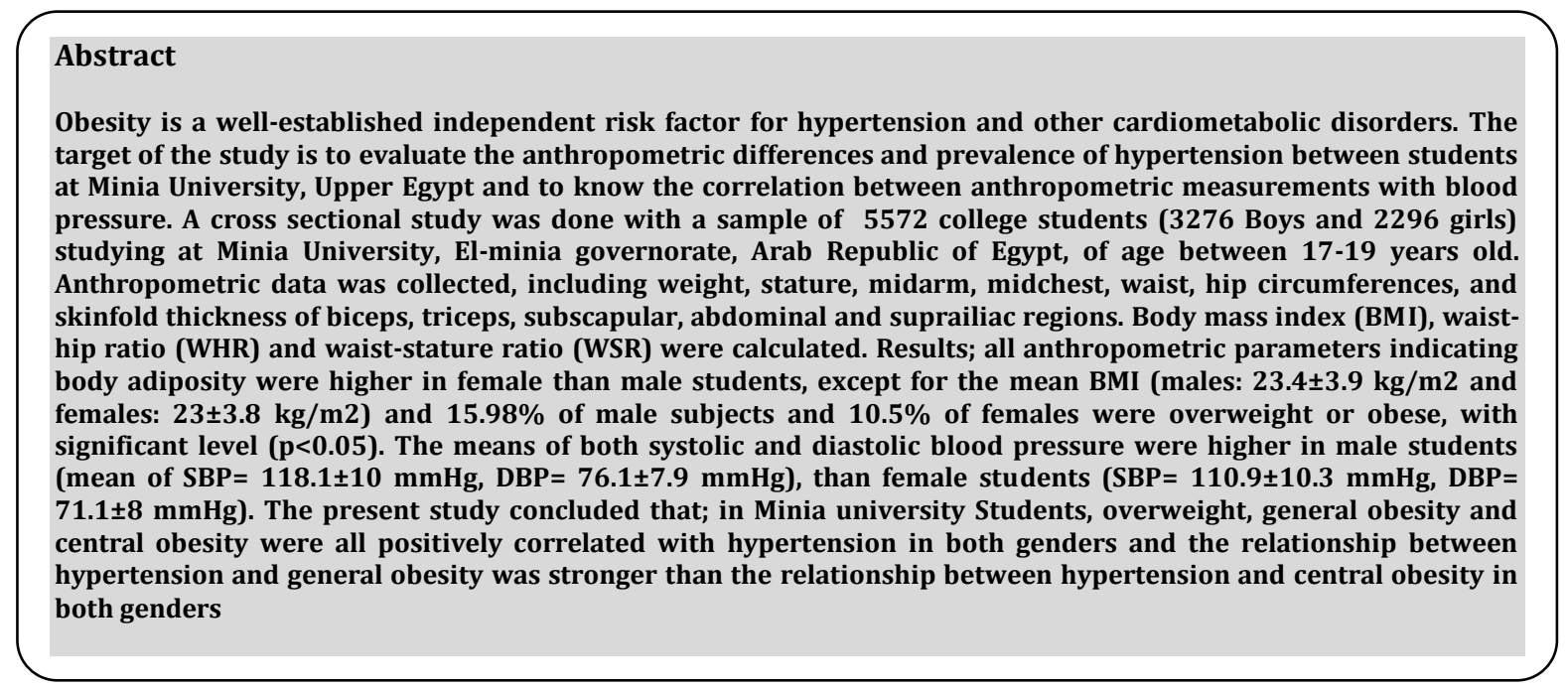

Keywords: obesity, blood pressure, adolescents, anthropometric measurements

\section{INTRODUCTION}

It is well known that obesity is one of the most critical public health problems worldwide. It is a significant independent risk factor for chronic diseases such as cardiovascular disease (CVD) and diabetes mellitus; obesity is also associated with high morbidity and mortality. Over the past 20 years, the prevalence of obesity has increased greatly worldwide, however; the best anthropometric index of obesity that predicts or associates strongly with hypertension and related conditions remains controversial and inconclusive (Sunder et al., 2013).

The rising prevalence of obesity worldwide was associated with an increased incidence of pre-hypertension and hypertension among younger population. Recent studies concerned to determine the prevalence of hypertension among university students. In addition, many studies attempted to know the association between excess body weight and its relation to hypertension (Sunder et al., 2013).

Hypertension is a common health problem affecting the cardiovascular system and indirectly impacts human health. The prevalence of hypertension in 2003-2004 in US was $29.3 \%$, and $7.3 \pm 0.9 \%, 32.6 \pm 2.0 \%$, and $66.3 \pm 1.8 \%$ in the 18 to 39,40 to 59 , and $\geq 60$ age groups, respectively (WHO, 2011). Age is an essential factor for prevalence of hypertension. Thus, analysis of agerelated hypertension is necessary (Moussa et al., 2016).

There are 2 main causes of hypertension; secondary hypertension, resulting from another medical condition, and essential hypertension, which has no identifiable cause. Essential hypertension is the most common form of hypertension. The specific causes for essential hypertension have not yet been identified, but there are risk factors that increase the incidence of hypertension, for example, alcohol consumption, stress, poor diet, lack of physical activity, smoking, etc. A combination of these factors may cause hypertension (Brennan et al., 2009). 
Adolescents have an increased incidence of elevated blood pressure and cardiovascular diseases. Several studies have shown that hypertension and pre-hypertension can start in adolescence, perhaps in the early stages of life, and continue into adulthood (Ejike et al., 2010).

Simple anthropometric measures were easy methods for the assessment of obesity. Two of the most commonly used anthropometric indices in clinical practice and population surveys are the body mass index (BMI) and the waist circumference (WC), indicating general obesity and central obesity, respectively. Others as waist circumference (WC), skin folds, waist to hip ratio (WHR), and fat percentage (FP) were significantly associated with cardiovascular diseases and prediction of elevated blood pressure, (Kang, 2013).

\section{SUBJECTS AND METHODS}

We performed a cross-sectional study involving a sample of 5572 college students (3276 boys and 2296 girls) studying at Minia University, El-Minia governorate, Arab Republic of Egypt. Male and female students who were apparently healthy and aged 17-19 years were recruited. All participants provided written informed consent before data collection. Blood pressure was measured using an Accoson mercury sphygmomanometer of appropriate cuff size and a Littman's stethoscope.

Measurements were done in a quiet room after a ten minutes rest by a single observer and Hypertension is defined and classified according to the WHO guidelines, pre-hypertensive (SBP: 120-139 $\mathrm{mmHg}$ and DBP: 80-89 mmHg), stage-1 hypertension (SBP: 140-159 mmHg and DBP: 90- $99 \mathrm{mmHg}$ ), stage-2 hypertension (SBP: >160 mmHg and DBP: >100 mmHg ), (Aounallah-skhiri et al., 2012). The mean of three readings was taken five minutes apart.

All participants were asked for wearing light clothes and no shoes. Weight was measured by a weighting scale (Momert, China) and recorded to the nearest 0.1 kilograms. Stature was measured using a stadiometer in barefoot subjects and averaged to the nearest 0.1 centimetre. Body mass index (BMI) was calculated as weight in kilograms divided by height in meter squared $\left(\mathrm{BMI}=\right.$ Weight $[\mathrm{Kg}] /$ Height $\left.[\text { meter }]^{2}\right)$.

Skinfold thickness was obtained using a skinfold caliper (Harpenden skinfold caliper) at biceps, triceps, abdominal, subscapular and suprailiac regions. All skin fold measurements were taken by the same observer. Measurements were taken on the right side of the body and the tester pinched the skin to raise a double layer of skin and adipose tissue. The calliper was then applied one $\mathrm{cm}$ below and at right angle to the pinch and recorded in millimeters one second later. The mean of three readings was taken, (Dwyer and Gibbons, 1994).

A stretch-resistant tape was used to measure to the nearest $0.1 \mathrm{~cm}$, the circumference of the right upper arm measured at the point of midway between the tip of the shoulder and the tip of the elbow (olecranon process and the acromion), (Yallamraju et al., 2014). Chest circumference is defined as the horizontal circular length taken just above the level of nipples during the period of quiet expiration, (Olweus et al., 1980). The waist circumference was measured at the midpoint between the lower margin of the last palpable rib and the top of the iliac crest, just above the level of umbilicus. Hip circumference was measured at the point yielding the maximum circumference over the buttocks. Waist-hip ratio (WHR) is then calculated as the ratio of the circumference of the waist to that of the hips. The WHO states that central obesity is defined as a waist-hip ratio above 0.90 for males and above 0.85 for females, or a body mass index (BMI) above 30.0, (WHO, 2011).

Waist-stature ratio (WSR) is identified as the waist circumference divided by the height. The WSR is another measure of the distribution of central body fat. Higher values of WSR indicate a higher risk of obesity-related cardiovascular diseases; it is correlated with abdominal obesity (Lee et al., 2008). In people under age of 40 years, the critical value of WSR should be less than 0.5 (Browning et al., 2010). Percent of body fat is calculated by using BMI; $=(1.20 \times \mathrm{BMI})+(0.23 \times$ age $)-(10.8 \times$ gender $)$ -5.4 , using for gender male $=1$ and female $=0$ (Wang et al., 2007).

Data entry and analysis were done by using statistical package for social sciences SPSS, version 25. Descriptive statistics are presented as a range (minimal \& maximal values) and mean \pm standard deviation (SD) for continuous variables. Groups compared using (student's t- test) for comparing between two groups. Association between two mutually dependent variables was done by using (Pearson's correlation coefficient), correlation ( $r$ ) was graded between +1 to be a positive correlation, -1 to be a negative correlation and if $(\mathrm{r}=0)$, indicates no association.

\section{RESULTS}

The mean of BMI in males $\left(23.4 \mathrm{Kg} / \mathrm{m}^{2}\right)$ was higher than in females $\left(22.9 \mathrm{Kg} / \mathrm{m}^{2}\right)$, (total of $\left.23.2 \mathrm{Kg} / \mathrm{m}^{2}\right)$. Subjects shared in the study were classified according to body mass index (BMI) into $13.24 \%$ were overweight and obese (15.98\% of male subjects and $10.5 \%$ of females). According to systolic blood pressure, subjects were classified into pre-hypertensive $14 \%$ (21\% of male subjects and $6.97 \%$ of female cases) and hypertensive $2.5 \%$ (3.91\% of male subjects and $0.45 \%$ of females) and according to diastolic blood pressure into pre-hypertensive $6.6 \%$ (8.85\% of male subjects and $3.31 \%$ of female cases) and hypertensive $7 \%$ ( $9.77 \%$ of male subjects and $2.87 \%$ of females). The number of pre-hypertensive and hypertensive cases was higher in male subjects than females.

In the histogram (Figure-1), the subjects were classified again according to the level of obesity depending on BMI and the means of systolic and diastolic levels of blood pressure to show the relationship between the mean of blood pressure and BMI. For the normal-weight subjects, the mean of (SBP: $113.52 \mathrm{mmHg}$ and DBP: $72.69 \mathrm{mmHg}$ ), overweight (SBP: $119.55 \mathrm{mmHg}$ and DBP; $77.83 \mathrm{mmHg}$ ) and obese cases (SBP: $128.62 \mathrm{mmHg}$ and DBP: $84.75 \mathrm{mmHg}$ ). Despite gradual increase of means of blood pressure with increased BMI, the maximum recorded value of systolic blood pressure $(180 \mathrm{mmHg})$ and diastolic blood pressure $\left(110 \mathrm{mmHg}\right.$ ) were found in the non-obese subjects with normal BMI $<25 \mathrm{~kg} / \mathrm{m}^{2}$. 
The means of both systolic and diastolic pressures were higher in males (SBP: $118.1 \pm 10$ and DBP: 76.1 \pm 7.9 ) than females (SBP: $110.9 \pm 10.3$ and DBP: $71.1 \pm 8.6$ ) as described in table- 1, and also the means of weight and stature were higher in males than females. Body mass index (BMI) was slightly higher in males, with a significant difference (P value $<0.01)$.

Measurements by skinfold caliper were higher in females than males; biceps, triceps, abdominal, subscapular, and suprailiac skinfolds. All measured circumferences were higher in male except for hip that was higher in females. Fat mass and fat percentage obtained by BMI- dependent equation were higher in females than males. Lean mass (non- fat mass) was obviously higher in males (59.4 \pm 7.1 to $43.7 \pm 5$ ). Waist hip ratio (WHR) was higher in males, while waist stature ratio was higher in females. All previously mentioned data indicated higher body fat in female, wider means of hip circumference and lesser WHR (feminine fat distribution).

For the association of systolic blood pressure in females, the BMI $(r=0.447)$, lean mass $(r=0.421)$, fat mass, $(r=0.453)$ and fat percentage, $(\mathrm{r}=0.446)$ were of the highest fair correlation as shown in table-2. Other variables had fair to weak correlation with systolic blood pressure. All measures were strongly significant (P- value is less than 0.01). Simple linear regression for female cases was done to obtain the constant and beta coefficient for predictive equation of mean of diastolic blood pressure. The correlation of diastolic blood pressure in females with BMI $(r=0.469)$, mid-chest $(r=0.436)$, waist $(r=0.412)$, hip circumferences $(r=0.441)$, fat mass $(r=0.453)$, fat percentage $(r=0.469)$ and lean mass $(r=0.451)$ were of high levels of fair correlation in female subjects, as shown in table-3. In males, -table 4- all variables had a fair positive correlation with the systolic blood pressure with the most striking parameters were BMI $(r=0.425)$, mid-arm $(r=0.436)$, mid-chest $(r=0.440)$, waist $(r=$ 0.438), hip $(r=0.455)$ circumferences, fat mass, fat percentage and lean mass $(r=0.410,0.429$ and 0.470 , respectively).

All skin-fold thickness measurements of higher correlation with systolic blood pressure in males than females by comparing of figures with table-2. Waist-hip ratio (WHR) of higher correlation with systolic blood pressure in male $(r=0.263)$, than females $(\mathrm{r}=0.117)$. Diastolic blood pressure in males had higher figures of correlation of measurements of skin fold thickness in table-5 when compared with those of female subjects in table-3. Increase fatness in males had a stronger positive association with diastolic blood pressure than in females.

Figure-1: Values of blood pressure according to BMI

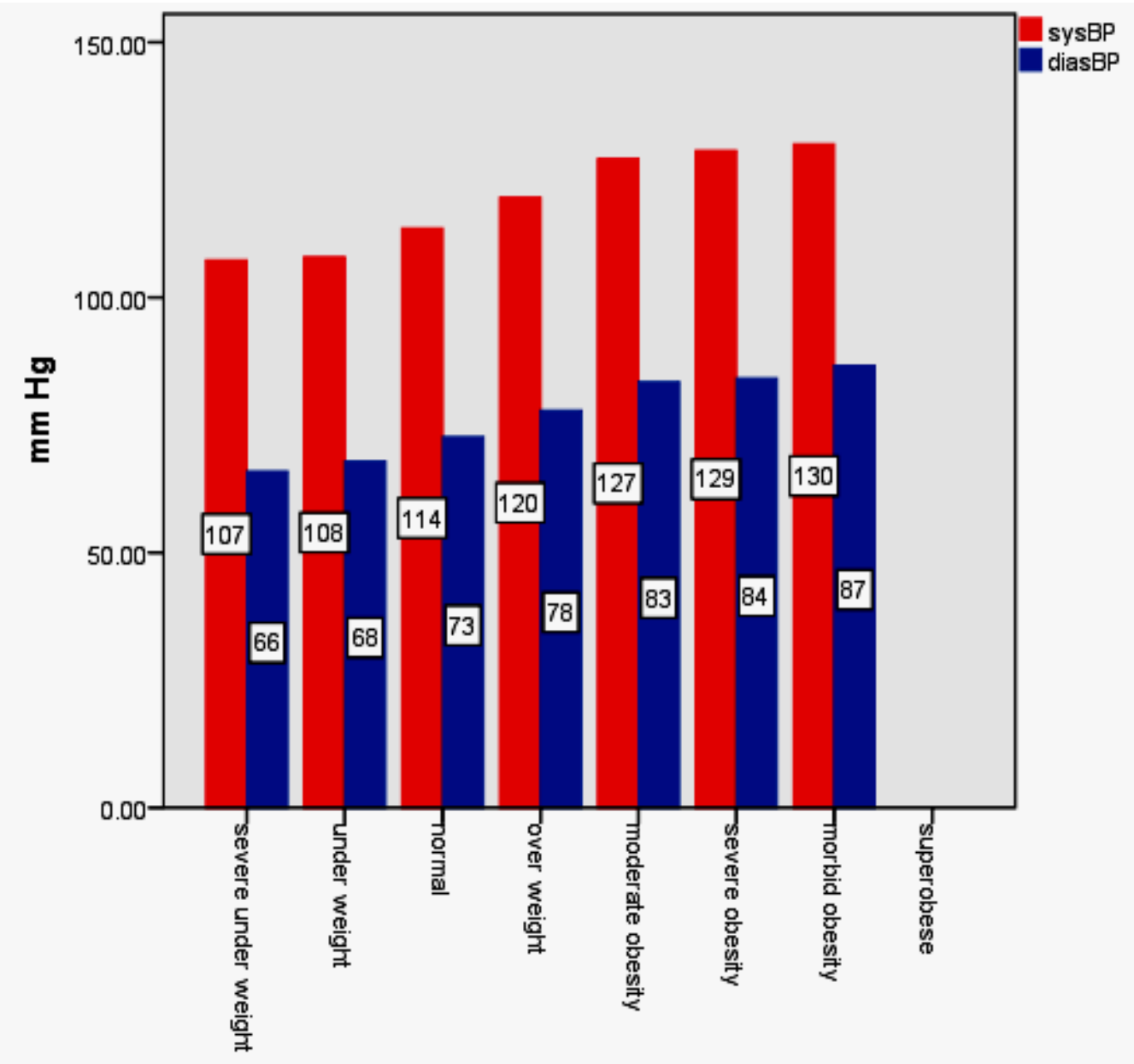

values of blood pressure according to BMI 
Citation: Medhat A. Salah and Abdelhamid S. Abobaker., Association between Obesity and Blood pressure incidence among Minia University Students, Upper Egypt. Australian Journal of Basic and Applied Sciences, 13(10): 33-41. DOI: 10.22587/ajbas.2019.13.10.5

Table 1: Independent samples T-test for quantitative data between the two sex groups

\begin{tabular}{|c|c|c|c|c|}
\hline & & \multicolumn{2}{|c|}{ Sex } & \multirow{3}{*}{ P-value } \\
\hline & & Female & Male & \\
\hline & & $\mathrm{N}=2296$ & $\mathrm{~N}=3276$ & \\
\hline SBP & $\begin{array}{r}\text { Range } \\
\text { Mean } \pm S D\end{array}$ & $\begin{array}{c}(85-145) \\
110.9 \pm 10.3\end{array}$ & $\begin{array}{l}(90-180) \\
118.1 \pm 10\end{array}$ & $<0.001 * *$ \\
\hline DBP & $\begin{array}{c}\text { Range } \\
\text { Mean } \pm S D\end{array}$ & $\begin{array}{l}(50-100) \\
71.1 \pm 8.6\end{array}$ & $\begin{array}{l}(55-110) \\
76.1 \pm 7.9\end{array}$ & $<0.001 * *$ \\
\hline Weight & $\begin{array}{c}\text { Range } \\
\text { Mean } \pm S D\end{array}$ & $\begin{array}{c}(35-105) \\
59.8 \pm 10.4\end{array}$ & $\begin{array}{c}(44-145) \\
71.4 \pm 12.8\end{array}$ & $<0.001 * *$ \\
\hline Stature & $\begin{array}{c}\text { Range } \\
\text { Mean } \pm S D\end{array}$ & $\begin{array}{l}(140-182) \\
161.3 \pm 5.4\end{array}$ & $\begin{array}{c}(154-193) \\
174.6 \pm 6\end{array}$ & $<0.001 * *$ \\
\hline BMI & $\begin{array}{c}\text { Range } \\
\text { Mean } \pm S D\end{array}$ & $\begin{array}{c}(14-40.5) \\
23 \pm 3.8\end{array}$ & $\begin{array}{l}(14.7-41) \\
23.4 \pm 3.9\end{array}$ & $<0.001 * *$ \\
\hline Biceps & $\begin{array}{c}\text { Range } \\
\text { Mean } \pm S D\end{array}$ & $\begin{array}{c}(2-36) \\
10.4 \pm 6.1\end{array}$ & $\begin{array}{c}(2-42) \\
7.2 \pm 4.2\end{array}$ & $<0.001 * *$ \\
\hline Triceps & $\begin{array}{c}\text { Range } \\
\text { Mean } \pm S D\end{array}$ & $\begin{array}{l}(6-46) \\
19 \pm 7.1\end{array}$ & $\begin{array}{c}(3-48) \\
12.7 \pm 6.4\end{array}$ & $<0.001 * *$ \\
\hline Abdomen & $\begin{array}{c}\text { Range } \\
\text { Mean } \pm S D\end{array}$ & $\begin{array}{c}(7-62) \\
27.3 \pm 8.3\end{array}$ & $\begin{array}{c}(4-64) \\
24.8 \pm 10.5\end{array}$ & $<0.001 * *$ \\
\hline Subscapular & $\begin{array}{c}\text { Range } \\
\text { Mean } \pm S D\end{array}$ & $\begin{array}{c}(5-52) \\
19.8 \pm 9.9\end{array}$ & $\begin{array}{c}(5-65) \\
18.7 \pm 8.7\end{array}$ & $<0.001 * *$ \\
\hline Suprailiac & $\begin{array}{c}\text { Range } \\
\text { Mean } \pm S D\end{array}$ & $\begin{array}{c}(5-58) \\
28.6 \pm 8.3\end{array}$ & $\begin{array}{c}(5-69) \\
24 \pm 11.6\end{array}$ & $<0.001 * *$ \\
\hline Midarm & $\begin{array}{c}\text { Range } \\
\text { Mean } \pm S D\end{array}$ & $\begin{array}{c}(19-41) \\
27.1 \pm 4.3\end{array}$ & $\begin{array}{c}(19-42) \\
28.6 \pm 3.2\end{array}$ & $<0.001 * *$ \\
\hline Midchest & $\begin{array}{c}\text { Range } \\
\text { Mean } \pm S D\end{array}$ & $\begin{array}{l}(70-121) \\
89.3 \pm 7.3\end{array}$ & $\begin{array}{l}(73-126) \\
94.3 \pm 7.8\end{array}$ & $<0.001 * *$ \\
\hline Waist & $\begin{array}{c}\text { Range } \\
\text { Mean } \pm S D\end{array}$ & $\begin{array}{l}(74-107) \\
77.6 \pm 8.5\end{array}$ & $\begin{array}{l}(75.5-130) \\
80.6 \pm 10.3\end{array}$ & $<0.001 * *$ \\
\hline Hip & $\begin{array}{c}\text { Range } \\
\text { Mean } \pm S D\end{array}$ & $\begin{array}{l}(74-122) \\
95.3 \pm 8.2\end{array}$ & $\begin{array}{c}(69.5-133) \\
94.7 \pm 8.7\end{array}$ & $0.018 *$ \\
\hline WHR & $\begin{array}{c}\text { Range } \\
\text { Mean } \pm S D\end{array}$ & $\begin{array}{c}(0.63-1) \\
0.81 \pm 0.06\end{array}$ & $\begin{array}{c}(0.7-1) \\
0.85 \pm 0.04\end{array}$ & $<0.001 * *$ \\
\hline WSR & $\begin{array}{c}\text { Range } \\
\text { Mean } \pm S D\end{array}$ & $\begin{array}{c}(0.35-0.66) \\
0.48 \pm 0.05\end{array}$ & $\begin{array}{c}(0.31-0.71) \\
0.46 \pm 0.06\end{array}$ & $<0.001 * *$ \\
\hline FM.BMI & $\begin{array}{c}\text { Range } \\
\text { Mean } \pm S D\end{array}$ & $\begin{array}{c}(5.4-49.5) \\
16.1 \pm 5.7\end{array}$ & $\begin{array}{c}(2.5-53.5) \\
12 \pm 6.5\end{array}$ & $<0.001 * *$ \\
\hline FP.BMI & $\begin{array}{c}\text { Range } \\
\text { Mean } \pm S D\end{array}$ & $\begin{array}{c}(15.3-47.1) \\
26.2 \pm 4.6\end{array}$ & $\begin{array}{c}(5.3-66.3) \\
16 \pm 4.7\end{array}$ & $<0.001 * *$ \\
\hline LM.BMI & $\begin{array}{c}\text { Range } \\
\text { Mean } \pm S D\end{array}$ & $\begin{array}{c}(29.6-62.7) \\
43.7 \pm 5\end{array}$ & $\begin{array}{c}(41.1-91.4) \\
59.4 \pm 7.1\end{array}$ & $<0.001 * *$ \\
\hline
\end{tabular}

*: Significant level taken at $\mathrm{P}$ value $<0.05$. - **: highly significant level at $\mathrm{P}$ value $<0.01$

Table 2: Correlation between systolic blood pressure and different body measures with simple linear regression analysis predicting systolic blood pressure in females

\begin{tabular}{|c|c|c|c|c|c|}
\hline & Constant & B coefficient & P-value & R & R2 \\
\hline BMI & 82.9 & 1.22 & $<0.001^{* *}$ & 0.447 & 0.200 \\
\hline Biceps & 104.96 & 0.57 & $<0.001^{* *}$ & 0.340 & 0.116 \\
\hline Triceps & 100.41 & 0.55 & $<0.001^{* *}$ & 0.380 & 0.145 \\
\hline Abdomen & 98.46 & 0.46 & $<0.001^{* *}$ & 0.366 & 0.134 \\
\hline Subscapular & 105.12 & 0.29 & $<0.001^{* *}$ & 0.281 & 0.079 \\
\hline Suprailiac & 97.66 & 0.46 & $<0.001^{* *}$ & 0.371 & 0.138 \\
\hline Midarm & 90.06 & 0.77 & $<0.001^{* *}$ & 0.322 & 0.104 \\
\hline Midchest & 58.47 & 0.59 & $<0.001^{* *}$ & 0.414 & 0.172 \\
\hline Waist & 74.4 & 0.47 & $<0.001^{* *}$ & 0.385 & 0.148 \\
\hline Hip & 63.24 & 0.5 & $<0.001^{* *}$ & 0.395 & 0.156 \\
\hline WHR & 93.19 & 21.73 & $<0.001^{* *}$ & 0.117 & 0.014 \\
\hline WSR & 76.9 & 70.6 & $<0.001^{* *}$ & 0.362 & 0.131 \\
\hline FM.BMI & 97.65 & 0.82 & $<0.001^{* *}$ & 0.453 & 0.205 \\
\hline FP.BMI & 84.39 & 1.01 & $<0.001^{* *}$ & 0.446 & 0.199 \\
\hline LM.BMI & 72.8 & 0.87 & $<0.001^{* *}$ & 0.421 & 0.177 \\
\hline
\end{tabular}


Citation: Medhat A. Salah and Abdelhamid S. Abobaker., Association between Obesity and Blood pressure incidence among Minia University Students, Upper Egypt. Australian Journal of Basic and Applied Sciences, 13(10): 33-41. DOI: 10.22587/ajbas.2019.13.10.5

SBP is the dependent variable

r: Pearson's correlation coefficient (0-0.24 weak), (0.25-0.49 fair), (0.5-0.74 moderate), (0.75-1 strong)

*: Significant level taken at $\mathrm{P}$ value $<0.05$. - **: highly significant level at $\mathrm{P}$ value $<0.01$.

Predictive equation: $\mathrm{SBP}=$ constant $+(\mathrm{B}$ coefficient $\mathrm{x}$ variable $)$

Table 3: Correlation between diastolic blood pressure and different body measures with Simple linear regression analysis predicting diastolic blood pressure in females

\begin{tabular}{|c|c|c|c|c|c|}
\hline & Constant & B coefficient & P-value & R & R2 \\
\hline BMI & 46.71 & 1.06 & $<0.001^{* *}$ & 0.469 & 0.220 \\
\hline Biceps & 66.76 & 0.42 & $<0.001^{* *}$ & 0.297 & 0.088 \\
\hline Triceps & 62.98 & 0.43 & $<0.001^{* *}$ & 0.353 & 0.125 \\
\hline Abdomen & 60.71 & 0.38 & $<0.001^{* *}$ & 0.367 & 0.135 \\
\hline Subscapular & 66.87 & 0.21 & $<0.001^{* *}$ & 0.246 & 0.060 \\
\hline Suprailiac & 60.13 & 0.38 & $<0.001^{* *}$ & 0.369 & 0.136 \\
\hline Midarm & 53.01 & 0.67 & $<0.001^{* *}$ & 0.337 & 0.113 \\
\hline Midchest & 25.29 & 0.51 & $<0.001^{* *}$ & 0.436 & 0.190 \\
\hline Waist & 38.07 & 0.42 & $<0.001^{* *}$ & 0.412 & 0.170 \\
\hline Hip & 26.92 & 0.46 & $<0.001^{* *}$ & 0.441 & 0.194 \\
\hline WHR & 58.01 & 16.02 & $<0.001^{* *}$ & 0.104 & 0.011 \\
\hline WSR & 41.21 & 62.08 & $<0.001^{* *}$ & 0.383 & 0.147 \\
\hline FM.BMI & 59.51 & 0.72 & $<0.001^{* *}$ & 0.476 & 0.227 \\
\hline FP.BMI & 47.93 & 0.88 & $<0.001^{* *}$ & 0.469 & 0.220 \\
\hline LM.BMI & 37.23 & 0.77 & $<0.001^{* *}$ & 0.451 & 0.203 \\
\hline
\end{tabular}

DBP is the dependent variable

Table 4: Correlation between systolic blood pressure and different body measures with simple linear regression analysis predicting systolic blood pressure in males

\begin{tabular}{|c|c|c|c|c|c|}
\hline & Constant & B coefficient & P-value & R & R2 \\
\hline BMI & 92.72 & 1.09 & $<0.001 * *$ & 0.425 & 0.181 \\
\hline Biceps & 111.62 & 0.91 & $<0.001 * *$ & 0.378 & 0.143 \\
\hline Triceps & 110.25 & 0.62 & $<0.001 * *$ & 0.399 & 0.159 \\
\hline Abdomen & 109.55 & 0.38 & $<0.001 * *$ & 0.396 & 0.157 \\
\hline Subscapular & 109.88 & 0.44 & $<0.001 * *$ & 0.383 & 0.147 \\
\hline Suprailiac & 110.1 & 0.34 & $<0.001 * *$ & 0.388 & 0.151 \\
\hline Midarm & 79.76 & 1.34 & $<0.001 * *$ & 0.436 & 0.190 \\
\hline Midchest & 65.02 & 0.56 & $<0.001 * *$ & 0.440 & 0.194 \\
\hline Waist & 83.8 & 0.43 & $<0.001 * *$ & 0.438 & 0.192 \\
\hline Hip & 68.45 & 0.53 & $<0.001 * *$ & 0.455 & 0.207 \\
\hline WHR & 65.41 & 62.14 & $<0.001 * *$ & 0.263 & 0.069 \\
\hline WSR & 87.21 & 66.96 & $<0.001 * *$ & 0.391 & 0.152 \\
\hline FM.BMI & 110.54 & 0.63 & $<0.001 * *$ & 0.410 & 0.168 \\
\hline FP.BMI & 103.62 & 0.91 & $<0.001 * *$ & 0.429 & 0.184 \\
\hline LM.BMI & 78.63 & 1.31 & $<0.001 * *$ & 0.470 & 0.221 \\
\hline
\end{tabular}

SBP is the dependent variable

Table 5: Correlation between diastolic blood pressure and different body measures with simple linear regression analysis predicting diastolic blood pressure in males

\begin{tabular}{|c|c|c|c|c|c|}
\hline & Constant & B coefficient & P-value & R & R2 \\
\hline BMI & 55.88 & 0.86 & $<0.001 * *$ & 0.430 & 0.185 \\
\hline Biceps & 70.82 & 0.74 & $<0.001 * *$ & 0.388 & 0.150 \\
\hline Triceps & 69.68 & 0.5 & $<0.001 * *$ & 0.411 & 0.169 \\
\hline Abdomen & 69.03 & 0.31 & $<0.001 * *$ & 0.413 & 0.171 \\
\hline Subscapular & 69.41 & 0.36 & $<0.001 * *$ & 0.394 & 0.155 \\
\hline Suprailiac & 69.47 & 0.28 & $<0.001 * *$ & 0.406 & 0.165 \\
\hline Midarm & 45.7 & 1.06 & $<0.001 * *$ & 0.439 & 0.192 \\
\hline Midchest & 33.95 & 0.45 & $<0.001 * *$ & 0.444 & 0.197 \\
\hline Waist & 48.79 & 0.34 & $<0.001 * *$ & 0.442 & 0.196 \\
\hline Hip & 36.53 & 0.42 & $<0.001 * *$ & 0.460 & 0.212 \\
\hline
\end{tabular}


Citation: Medhat A. Salah and Abdelhamid S. Abobaker., Association between Obesity and Blood pressure incidence among Minia University Students, Upper Egypt. Australian Journal of Basic and Applied Sciences, 13(10): 33-41. DOI: 10.22587/ajbas.2019.13.10.5

\begin{tabular}{|c|c|c|c|c|c|}
\hline WHR & 34.42 & 49.11 & $<0.001 * *$ & 0.264 & 0.070 \\
\hline WSR & 51.21 & 53.88 & $<0.001 * *$ & 0.399 & 0.159 \\
\hline FM.BMI & 70.14 & 0.5 & $<0.001 * *$ & 0.408 & 0.167 \\
\hline FP.BMI & 64.57 & 0.72 & $<0.001 * *$ & 0.432 & 0.187 \\
\hline LM.BMI & 45.17 & 0.52 & $<0.001 * *$ & 0.468 & 0.219 \\
\hline
\end{tabular}

DBP is the dependent variable

\section{ABBREVIATIONS}

SBP: Systolic blood pressure $(\mathrm{mmHg})$, DBP: Diastolic blood pressure $(\mathrm{mmHg})$, weight $(\mathrm{Kg})$, stature (cm), Biceps: biceps skinfold (mm), Triceps: triceps skinfold (mm), Abdomen: abdominal skinfold (mm), Subscapular: subscapular skinfold (mm), Suprailiac: suprailiac skinfold $(\mathrm{mm})$, Midarm: midarm circumference $(\mathrm{cm})$, Midchest: midchest circumference (cm), Waist: waist circumference $(\mathrm{cm})$, Hip: hip circumference $(\mathrm{cm})$, WHR: waist-hip ratio, WSR: waist-stature ratio, BMI: body mass index $\left(\mathrm{Kg} / \mathrm{m}^{2}\right)$, FM.BMI: Fat mass by BMI derived equation $(\mathrm{Kg})$, FP.BMI: Fat percentage by BMI derived equation (\%),LM.BMI: Lean mass by BMI derived equation $(\mathrm{Kg})$.

\section{DISCUSSION}

The prevalence of obesity has increased worldwide and has nearly doubled between 1980 and 2008. A large number of studies have shown that obesity increases the hypertension incidence; and the relationship between obesity and hypertension differs according to age, gender, geographical area and race (Song et al., 2014). Increase in the body fat was associated with increased blood pressure and both are risk factors for increased cardiovascular morbidity and mortality. Hypertension and obe sity may have their start of occurrence during adolescence (Mushengezi and Chillo, 2014).

In the present work, the mean of BMI in males $\left(23.4 \mathrm{Kg} / \mathrm{m}^{2}\right)$ was higher than in females $\left(22.9 \mathrm{Kg} / \mathrm{m}^{2}\right)$, total of $23.2 \mathrm{Kg} / \mathrm{m}^{2}$ for both sexes. These results were reversed in Bahraini adolescents, the mean of BMI in males was $21.65 \mathrm{Kg} / \mathrm{m}^{2}$ and in females was $23.38 \mathrm{Kg} / \mathrm{m}^{2}$ (total of $22.55 \mathrm{Kg} / \mathrm{m}^{2}$ ) (Al-Sendi et al., 2003). The mean of BMI was higher in female than male students of PortSaid University $\left(25.9 \mathrm{Kg} / \mathrm{m}^{2}\right.$ males to $27.1 \mathrm{Kg} / \mathrm{m}^{2}$ females) and among Damietta students $\left(26.6 \mathrm{Kg} / \mathrm{m}^{2} \mathrm{males}\right.$ to $27.7 \mathrm{Kg} / \mathrm{m}^{2}$ females) (Moussa et al., 2016).

In Brazil, the mean of BMI for the same age group in males was $23.2 \mathrm{Kg} / \mathrm{m}^{2}$ and in females was $20.8 \mathrm{Kg} / \mathrm{m}^{2}$ (total of 21.9 $\mathrm{Kg} / \mathrm{m}^{2}$ ) (Martins et al., 2010), in Korean adolescents, the mean of BMI was $\left(21.6 \mathrm{Kg} / \mathrm{m}^{2}\right.$ males to $20.3 \mathrm{Kg} / \mathrm{m}^{2}$ females) $($ Song et al., 2014), and in Malaysian adolescents the mean of BMI was $23.3 \mathrm{Kg} / \mathrm{m}^{2}\left(23.5 \mathrm{Kg} / \mathrm{m}^{2}\right.$ males to $23.1 \mathrm{Kg} / \mathrm{m}^{2}$ females) (Cheah et al., 2018).

In the current study, about $13.24 \%$ of the respondents were overweight or obese according to BMI (15.98\% of male subjects and $10.5 \%$ of females). In other studies on college students in Louisiana, United States of America 57.7\% of adolescents were obese(Deshmukh-Taskar et al., 2006), in Alexandria governorate, Egypt; overall obesity prevalence based on BMI was $10.3 \%$ (11.8\% males and $8.7 \%$ females)(Abolfotouh et al., 2011), in Damietta governorate, obesity prevalence was $52 \%$ (47.9\% of male subjects and $56.4 \%$ of females), in Port-Said, obesity prevalence was $46.9 \%$ (44.2\% of male subjects and $49.6 \%$ of females) (Moussa et al., 2016). In Spain, Madrid, (25.75\% of male subjects and 24.4\% of females) (Serrano et al., 2013), in Brazil, the obesity level was $18.2 \%$ for 18 years old of age (Martins et al 2010), in Nigeria, 17.3\% were obese (Akindele et al., 2016), in Malaysia, the level of overweight and obesity derived from BMI was 40.7\% (Cheah et al. 2018).

Hypertension is a public health problem and it is important to be a step towards early intervention, the present study described the proportion of adolescents with systolic and diastolic hypertension as $2.5 \%$ and $7 \%$ respectively, the findings are different from those found in secondary school adolescents in Dar Essalam, Tanzania, where the prevalence was higher in systolic hypertension to be $17.5 \%$, but the diastolic hypertension was nearly similar per cent, 5.5\% (Mushengezi and Chillo, 2014). Both systolic and diastolic hypertension found in urban school in Chennai, India where the prevalence was higher at the level of $21.5 \%$ for both systolic and diastolic hypertension (Sundar et al., 2013).

In this study, we found that the mean of systolic and diastolic blood pressure was greater in males (SBP: $118.14 \mathrm{mmHg}$ to DBP: $76.09 \mathrm{mmHg}$ ) than females (SBP: $110.89 \mathrm{mmHg}$ to DBP: $71.06 \mathrm{mmHg}$ ). In other studies, similar results were found in Bahrain, as the mean values blood pressure in males (SBP: $122.9 \mathrm{mmHg}$ to DBP: $72.1 \mathrm{mmHg}$ ) were higher than females (SBP: 118.6 mmHg to DBP: $70.1 \mathrm{mmHg}$ ) (Al-Sendi et al., 2003), in Brazil, the mean values blood pressure in males (SBP: $124.1 \mathrm{mmHg}$ to DBP: $80.2 \mathrm{mmHg}$ ) were higher than females (SBP: $113.5 \mathrm{mmHg}$ to DBP: $72.8 \mathrm{mmHg}$ )(Martins et al., 2010), and also in Indonesia, the mean blood pressure in males (SBP: $113 \mathrm{mmHg}$ to DBP: $77.17 \mathrm{mmHg}$ ) and in females (SBP: $102.58 \mathrm{mmHg}$ to DBP: $70.67 \mathrm{mmHg}$ ) (Hastuti et al., 2018), while the diastolic blood pressure was greater in adolescent girls (DBP in girls: 71 $\mathrm{mmHg}$ ) than boys (DBP: $68 \mathrm{mmHg}$ ) in Tanzania (Mushengezi and Chillo, 2014).

The percent of subjects with elevated blood pressure collectively, Pre-hypertensive and hypertensive cases was of higher prevalence in males (systolic: $14.64 \%$ and diastolic: $10.95 \%$ ) than females (systolic: $3 \%$ and diastolic hypertension: $2.55 \%$ ). According to the national survey studies in Egypt, the hypertension prevalence had increased with age from 7.8\% in $25-$ to $34-$ year-olds to $56.6 \%$ in those 75 years or older and according to sex, (Ibrahim et al., 1995). Hypertension in Egypt was slightly more common in adult women than in men (26.9\% versus $25.7 \%$, respectively), (Hasan et al., 2014), According to the survey 
studies in Saudi Arabia, the hypertension prevalence had increased with age from $8.8 \%$ in 15 - to 25 -year-olds, $12.9 \%$ in 26 - to 35 year-olds to $57.5 \%$ in those $60-75$ years or older and according to sex.

Body mass index (BMI); which reflects general body fatness, was a risk factor for elevated blood pressure, which was consistent with other studies reflecting the link between high body fat and high blood pressure (Gus et al., 2004). BMI can be easily measured and it is a simple tool for screening of obesity and hypertension. Although BMI is the most frequently used method to assess the level of obesity, BMI doesn't differentiate between body lean mass and body fat mass; that is a person can have high BMI, but still have low-fat mass, like athletes and vice versa (Fox et al., 2007).

In the present study, rising of the mean of both systolic and diastolic blood pressure was associated with overweight and obesity according to BMI, in normal subjects (the mean of SBP: $109.5 \mathrm{mmHg}$ and mean of DBP: $68.8 \mathrm{mmHg}$ ) and in overweight and obese (the mean of SBP: $126.33 \mathrm{mmHg}$ and mean of DBP: $83.02 \mathrm{mmHg}$ ), these findings was in agreement with what reported by (Song et al., 2014), in normal Korean adolescent subjects (the mean of SBP: $110.9 \mathrm{mmHg}$ and mean of DBP: $60.45 \mathrm{mmHg}$ ) and in overweight and obese (the mean of SBP: $119.8 \mathrm{mmHg}$ and mean of DBP: $64.45 \mathrm{mmHg}$ ), Spanish adolescents (the mean of SBP: $111.86 \mathrm{mmHg}$ and mean of DBP: $63.43 \mathrm{mmHg}$ ) and in overweight and obese (the mean of SBP: $117.1 \mathrm{mmHg}$ and mean of DBP: $68.77 \mathrm{mmHg}$ )(Serrano et al., 2013).

The correlation of BMI and blood pressure was described as fair correlation in our students, BMI ( $\mathrm{r}=0.426$ for SBP with beta coefficient 1.1 and for DBP, $r=0.441$ with beta coefficient 0.97). With similar findings in another study, on Indonesian adolescents, the correlation of BMI and blood pressure, also was fair ( $r=0.32$ for SBP with beta coefficient 0.82 and for DBP, $r=$ 0.27 with beta coefficient 0.54) (Hastuti et al., 2018), and in Bahrain, the correlation was ( $r=0.431$ for SBP with beta coefficient 0.98 and for DBP, $r=0.446$ with beta coefficient 0.97) (Al-Sendi et al., 2003).

Weight is a simple measure of obesity (Stamler, 1997). Increasing weight has been related to increased salt retention and insulin resistance which may be the cause of hypertension (Rocchini et al., 1989); adipose tissue has the ability to produce angiotensinogen that involved in pathogenesis of elevated blood pressure. The correlation between BMI and angiotensinogen production had been documented in Nigerian and Jamaican population samples (Rotimi et al., 1996). Another explanation of the link between hypertension and adiposity is the deposition of lipids into non adipose organs, such as kidney, which lead to accumulation of toxic metabolites derived from metabolism of fats and resulted in obesity-related glomerulopathy (Unger et al., 2010).

However, the changes in body fat distribution pattern is not linear with BMI and vary by sex and age, so the recent studies using accurate methods of determination of fat percentage as DXA and bioelectrical impedance analysis weakened the association between BMI and body fatness (Nagaraj et al., 2018).

\section{CONCLUSION}

$13.24 \%$ of the students were overweight and obese, the mean of BMI in males was higher than in females, there was a gradual increase of means of blood pressure with increased BMI. The number of pre-hypertensive and hypertensive cases was higher in male subjects than in females, increase fatness in males had a stronger positive association with diastolic blood pressure than in females.

\section{REFERENCES}

Abolfotouh, M. A., Sallam, S. A., Mohammed, M. S., Loutfy, A. A., \& Hasab, A. A. (2011). Prevalence of elevated blood pressure and association with obesity in Egyptian school adolescents. International journal of hypertension, 2011.

Akindele, M. O., J. S. Phillips and E. U. Igumbor (2016). "The relationship between body fat percentage and body mass index in overweight and obese individuals in an urban african setting." Journal of public health in Africa 7(1).

Al-Sendi, A., P. Shetty and A. Musaiger (2003). "Prevalence of overweight and obesity among Bahraini adolescents: a comparison between three different sets of criteria." European journal of clinical nutrition 57(3): 471.

Aounallah-Skhiri, H., J. El Ati, P. Traissac, H. B. Romdhane, S. Eymard-Duvernay, F. Delpeuch, N. Achour and B. Maire (2012). "Blood pressure and associated factors in a North African adolescent population. A national cross-sectional study in Tunisia." BMC Public Health 12(1): 98.

Brennan, P., J. McKay, L. Moore, D. Zaridze, A. Mukeria, N. Szeszenia-Dabrowska, J. Lissowska, P. Rudnai, E. Fabianova and D. Mates (2009). "Obesity and cancer: Mendelian randomization approach utilizing the FTO genotype." International journal of epidemiology 38(4): 971-975.

Browning, L. M., S. D. Hsieh and M. Ashwell (2010). "A systematic review of waist-to-height ratio as a screening tool for the prediction of cardiovascular disease and diabetes: 0.5 could be a suitable global boundary value." Nutrition research review s 23(2): 247-269.

Cheah, W., Ensayan, J. M., Helmy, H., \& Chang, C. (2018). Hypertension and its association with Anthropometric indices among students in a public university. Malaysian Family Physician: the Official Journal of the Academy of Family Physicians of Malaysia, 13(1), 2. 
Citation: Medhat A. Salah and Abdelhamid S. Abobaker., Association between Obesity and Blood pressure incidence among Minia University Students, Upper Egypt. Australian Journal of Basic and Applied Sciences, 13(10): 33-41. DOI: 10.22587/ajbas.2019.13.10.5

Deshmukh-Taskar, P., T. Nicklas, M. Morales, S. Yang, I. Zakeri and G. Berenson (2006). "Tracking of overweight status from childhood to young adulthood: the Bogalusa Heart Study." European journal of clinical nutrition 60(1): 48.

Dwyer, T., \& Gibbons, L. (1994). The Australian Schools Health and Fitness Survey. Physical fitness related to blood pressure but not lipoproteins. Circulation, 89(4), 1539-1544.

Ejike, C. E., C. E. Ugwu and L. U. Ezeanyika (2010). "Variations in the prevalence of point (pre) hypertension in a Nigerian school-going adolescent population living in a semi-urban and an urban area." BMC pediatrics 10(1): 13.

Fox, C. S., J. M. Massaro, U. Hoffmann, K. M. Pou, P. Maurovich-Horvat, C.-Y. Liu, R. S. Vasan, J. M. Murabito, J. B. Meigs and L. A. Cupples (2007). "CLINICAL PERSPECTIVE." Circulation 116(1): 39-48.

Gus, M., S. C. Fuchs, L. B. Moreira, R. S. Moraes, M. Wiehe, A. F. Silva, F. Albers and F. D. Fuchs (2004). "Association between different measurements of obesity and the incidence of hypertension." American journal of hypertension 17(1): 50-53.

Hastuti, J., N. T. Rahmawati and R. A. Suriyanto (2018). "Anthropometric Indicators for Blood Pressure and the Prevalence of Hypertension in Indonesian College Students Aged 18-25 Years." Pakistan Journal of Nutrition 17(4): 163-170.

Ibrahim, M. M., H. Rizk, L. J. Appel, W. E. Aroussy, S. Helmy, Y. Sharaf, Z. Ashour, H. Kandil, E. Roccella and P. K. Whelton (1995). "Hypertension prevalence, awareness, treatment, and control in Egypt: results from the Egyptian National Hypertension Project (NHP)." Hypertension 26(6): 886-890.

Kang, Y. S. (2013). Obesity associated hypertension: new insights into mechanism. Electrolytes \& Blood Pressure, 11(2), 46-52.

Lee, C. M. Y., R. R. Huxley, R. P. Wildman and M. Woodward (2008). "Indices of abdominal obesity are better discriminators of cardiovascular risk factors than BMI: a meta-analysis." Journal of clinical epidemiology 61(7): 646-653.

M Hasan, D., A. H Emeash, S. B Mustafa, E. A. Abdelazim and A. Alaa El-din (2014). "Hypertension in Egypt: a systematic review." Current hypertension reviews 10(3): 134-141.

Martins, M. d. C. d. C., Ricarte, I. F., Rocha, C. H. L., Maia, R. B., Silva, V. B. d., Veras, A. B., \& Souza Filho, M. D. d. (2010). Blood pressure, excess weight and level of physical activity in students of a public university. Arquivos brasileiros de cardiologia, 95(2), 192-199.

Moussa, M. M. M., El-Mowafy, R. I., \& El-Ezaby, H. H. (2016). Prevalence of hypertension and associated risk factors among university students: Comparative study. Journal of Nursing Education and Practice, 6(5), 19.

Mushengezi, B. and P. Chillo (2014). "Association between body fat composition and blood pressure level among secondary school adolescents in Dar es Salaam, Tanzania." The Pan African medical journal 19.

Nagaraj, A., W. Arnold, W. King, J. Kissel and B. Elsheikh (2018). Evaluation of lean mass through DXA scanning and the correlation to functional outcomes in adults with SMA.(S46. 005), AAN Enterprises.

Olweus, D., Mattsson, Å., Schalling, D., \& Loew, H. (1980). Testosterone, aggression, physical, and personality dimensions in normal adolescent males. Psychosomatic medicine.

Organization, W. H. (2011). Waist circumference and waist-hip ratio: report of a WHO expert consultation, Geneva, 8-11 December 2008.

Rocchini, A. P., J. Key, D. Bondie, R. Chico, C. Moorehead, V. Katch and M. Martin (1989). "The effect of weight loss on the sensitivity of blood pressure to sodium in obese adolescents." New England Journal of Medicine 321(9): 580-585.

Rotimi, C., A. Puras, R. Cooper, N. McFarlane-Anderson, T. Forrester, O. Ogunbiyi and L. Morrison Ryk Ward (1996). "Polymorphisms of renin-angiotensin genes among Nigerians, Jamaicans, and African Americans." Hypertension 27(3): 558-563.

Serrano, M. D. M., Armesilla, M. D. C., Moreno, M. M. C., de Espinosa, M. G.-M., López-Ejeda, N., Álvarez, J. R. M., . . Romero-Collazos, J. F. (2013). Association between adiposity and blood pressure levels between the ages of 6 and 16 years. Analysis in a student population from Madrid, Spain. Revista Española de Cardiología (English Edition), 66(2), 110-115.

Song, Y.-H., Kim, H. S., Park, H. S., Jung, J. W., Kim, N. S., Noh, C. I., \& Hong, Y. M. (2014). Sex differences in the relation of body composition to cardiovascular parameters and functions in Korean adolescents: a school-based study. Obesity facts, 7(3), 165-177.

Stamler, J. (1997). "The INTERSALT Study: background, methods, findings, and implications." The American journal of clinical nutrition 65(2): 626S-642S.

Sundar, J. S., J. Adaikalam, S. Parameswari, S. Valarmarthi, S. Kalpana and D. Shantharam (2013). "Prevalence and determinants of hypertension among urban school children in the age group of 13-17 years in, Chennai, Tamilnadu." Epidemiol 3(130): 2161-1165.1000130. 
Unger, R. H., G. O. Clark, P. E. Scherer and L. Orci (2010). "Lipid homeostasis, lipotoxicity and the metabolic syndrome." Biochimica et Biophysica Acta (BBA)-Molecular and Cell Biology of Lipids 1801(3): 209-214

Wang, Z., S. Heshka, J. Wang, D. Gallagher, P. Deurenberg, Z. Chen and S. B. Heymsfield (2007). "Metabolically active portion of fat-free mass: a cellular body composition level modeling analysis." American Journal of Physiology-Endocrinology and Metabolism 292(1): E49-E53.

Yallamraju, S. R., R. Mehrotra, A. Sinha, S. R. Gattumeedhi, A. Gupta and S. V. Khadse (2014). "Use of mid upper arm circumference for evaluation of nutritional status of OSMF patients." Journal of International Society of Preventive \& Community Dentistry 4(Suppl 2): S122. 